\title{
Nested Polymerase Chain Reaction (Nested-PCR) As A Diagnostic Technique for Intestinal Helminth Infection
}

\author{
Reqgi First Trasia ${ }^{1}$ \\ Bagian Parasitologi, Fakultas Kedokteran, Universitas Sultan Ageng Tirtayasa, \\ Jalan Raya Jakarta, Km 4, Pakupatan, Kota Serang, Provinsi Banten \\ Penulis untuk korespondensi/email: reqgifirsttrasia@gmail.com
}

\begin{abstract}
Worm infections are still a health problem in the world, involving Indonesia. This disease generally rarely causes death, it has a detrimental impact on society such as malnutrition, anemia, productivity declining, and inhibits physical growth and intelligence in children. Efforts to support the intestinal helminth infection elimination program must be supported by proper diagnosis so that it can be continued with appropriate treatment and as a guideline for determining further policy. Microscopic examination is currently still the most commonly used method but has a limitation, especially less sensitive if in conditions of low infection. Molecular diagnoses suc [1]h as PCR can provide an alternative in providing a more sensitive and specific diagnosis of intestinal helminth infection.
\end{abstract}

Keywords - Diagnosis, Intestinal helminth infections, Polymerase Chain Reaction

\section{INTRODUCTION}

Worm infections caused by intestinal helminth parasites are still a health problem in the world, including Indonesia. World Health Organization (WHO) estimates that more than 1.5 billion people, or around $24 \%$ of the world's population, are infected with intestinal helminths in various parts of the world. [1] The prevalence of intestinal helminth infections in Indonesia is generally very high, especially in population groups with low socioeconomic level, and poor sanitation. [2] The prevalence of intestinal helminth infections in elementary school children in 2012-2013 ranges from $0.5-86 \%$ with an average national prevalence of $28 \%$. [3]

Common causes of intestinal helminth infections are Ascaris lumbricoides (roundworms), Trichuris trichiura (whipworms), Ancylostoma duodenale and, Necator americanus (hookworms). [4]

Intestinal helminth infections often show no symptoms but can affect intake, digestion, absorption, and food metabolism which can cumulatively cause a lack of calories and protein and blood loss in sufferers, causing anemia. In addition to inhibiting physical development, intelligence, and productivity, intestinal helminth infections can also reduce the body's resistance so it is susceptible to other diseases

Efforts to control and eliminate intestinal helminth infections can be done by administering helminthic drugs or anthelmintics (anthelmintics) in bulk and counseling about the importance of hygiene and sanitation practice. [5] To support efforts to control and eliminate this, it is necessary to diagnose intestinal helminth infections quickly and accurately. Diagnosis of intestinal helminth infections commonly performed by microscopic, one of which is the Kato-Katz technique, which is a technique recommended by WHO. [6] In general, microscopic techniques have the advantages of being simple, easy, and inexpensive, but have limitations. Some of these limitations are not sensitive, especially if the number of eggs in the sample examined is small [7], requires skilled microscopic personnel and lack of standardization in the process of sample collection, preparation of protocols, inspection process, and application of external quality assessment schemes. [7] Use of the PCR molecular now widely used as an alternative for the diagnosis of intestinal helminth infections because it produces detection of infections that are sensitive, specific and fast. [8] The technique is carried out by detecting the presence of genetic material or Deoxyribonucleic Acid (DNA) parasites 
in the samples examined. Based on this background, this article will discuss PCR as a diagnostic technique for intestinal helminth infections.

\section{INTESTINAL HELMINTH INFECTION}

Humans are the host of several worms that are included in the group of intestinal nematodes. Disease caused by intestinal helminth infections is one of the neglected tropical diseases. This disease is often underestimated. After all, its effects are not deadly, but very detrimental because it can reduce productivity and inhibit physical and cognitive growth in children. Also, this disease is synonymous with people who have low socioeconomic and educational levels

Included in the group of intestinal helminths are roundworms (Ascaris lumbricoides, Toxocara canis, Toxocara cati), whipworms (Trichuris trichiuria), and hookworms (Necator americanus, Ancylostoma duodenale, Ancylostoma braziliense, Ancylostoma ceylanicum), and hookworm (Necator americanus, Ancylostoma duodenale, Ancylostoma braziliense, Ancylostoma ceylanicum). [9] However, there are four main types of intestinal helminth infections, namely $A$. lumbricoides (roundworms), T. trichiura (whipworms), A. duodenale and $N$. americanus (hookworms).

\section{Polymerase Chain Reaction (PCR)}

PCR is a technique in molecular biology that aims to amplify or duplicate the desired DNA segments in vitro. This technique was first developed by Karry Mullis in 1985. In the PCR technique, the target DNA segment can be amplified in millions in just a few hours. [10]The PCR technique is very sensitive and specific because only a small sample can detect certain DNA sequences. [11] PCR very useful and considered important in various fields such as the health sector, which is useful for the identification of viruses, bacteria, parasite, or fungi that cause infection of disease. [12] Components needed in PCR are target DNA (DNA template); a pair of primers, that is, a short nucleotide that has a nucleotide sequence that is complementary to the nucleotide sequence in the DNA template; dNTPs (deoxynucleotide triphosphates, i.e. dATP, dCTP, dGTP, and dTTP); and DNA polymerase enzymes

The PCR process consists of 3 stages: denaturation (denaturation) of DNA at high temperatures ( $94^{\circ}$ C), primary attachment (annealing) at temperatures of $45-55^{\circ} \mathrm{C}$, and elongation (extension) at $72^{\circ} \mathrm{C}$.
[13]. The results of the PCR can then be visualized using electrophoresis, one of the commonly used methods is electrophoresis using agarose gels, to detect the presence or absence of target DNA products.

\section{PCR to Diagnose Intestinal Worm Infection}

Until now, there have been many attempts to apply and develop PCR techniques to diagnose STH infections. Some PCR techniques used are nested PCR and real-time PCR.

\section{Nested PCR}

This nested PCR is a development of the PCR reaction that is designed to increase specificity by reducing the non-specific binding (non-specific) of the PCR product. This technique requires the same components as conventional PCR, but differ in the number of primers used and the number of PCR processes performed. In the nested PCR technique using two pairs of primers, one primer is used in the first PCR reaction, which is then followed by the second PCR reaction using the first PCR product and with the second set of primers. [14]

Despite its high sensitivity, this method has the disadvantage of the possibility of contamination arising during the transfer of the first amplified product to the tube to be processed at the second amplification stage. To reduce the level of contamination, primers can be used which are designed to stick to different temperatures, or by adding ultra-pure oil to separate the mixture of the two PCR products. [15]

Two different primers on a nested PCR, namely the outside and inside primers, can also be modified by reusing the outside primer on the first PCR, and adding different primers inside the second PCR; which is called nested PCR. George et al. has used the semi-nested PCR method to distinguish species from three STH genera namely Ascaris, Trichuris, and hookworm. From a total of 207 study samples, A. lumbricoides were detected in 71 (34.2\%) samples, T. trichiura $87(42.0 \%)$ samples, $N$. americanus 73 (35\%) samples and A. duodenale 40 (31.5) \%) sample. [1]

\section{CONCLUSION}

Diagnosis based on molecular examination such as PCR especially nested PCR is a hope promising tools for detection of intestinal helminth infections. High sensitivity and specificity in detecting 
parasites can be a solution if applied in areas with low intestinal helminth endemicity or in nonendemic areas. So that government programs are not only aimed at reducing infection rates, but can also shift to break the chain of transmission. In certain cases there are still less than optimal performance from the PCR method, so that standardization is still needed that can be considered.

\section{REFERENCES}

[1] World Health Organization, Februari 2018. [Online]. Available: https://www.who.int/news-room/factsheets/detail/soil-transmitted-helminthinfections.

[2] Kementrian Kesehatan Republik Indonesia, Peraturan Menteri Kesehatan Republik Indonesia Nomor 15 Tahun 2017 tentang Penanggulangan Kecacingan, S. F. d. Kecacingan, Penyunt., Jakarta: Kementrian Kesehatan Republik Indonesia, 2017.

[3] Anorital, R. M. Dewi dan K. Palupi, "Studi kajian Upaya Pemberian Obat Pencegah Masal Filarisasi Terhadap Pengendalian Penyakit Infeksi Kecacingan," Jurnal Biotek Medisiana Indonesia, vol. 5, no. 2, pp. 95 -103, 2016.

[4] R. Anderson, S. Farrel, H. Turner, J. Walson dan C. A. D. \&. J. Truscott, "Assessing the interruption of the transmission of human helminths with mass drug administration alone: optimizing the design of cluster randomized trials," Parasites \& Vectors, vol. 10, no. 93, 2017.

[5] R. M. Anderson, H. C. Turner, J. E. Truscott, T. D. Hollingsworth dan S. J. Brooker, "Should the Goal for the Treatment of Soil Transmitted Helminth (STH) Infections Be Changed from Morbidity Control in Children to Community-Wide Transmission Elimination?," Plos Neglected Tropical Diseases, vol. 9, no. 8, August 2015.

[6] M. D. Lim, S. J. Brooker, V. Y. Jr Belizario, et all, "Diagnostic tools for soil-transmitted helminths control and elimination programs: A pathway for diagnostic product development," Plos Neglected Tropical Diseases, vol. 12, no. 3, Maret 2018.
[7] J. C. Dunn, H.C. Turner, A. Tun, R. M. Anderson, "Epidemiological surveys of, and research on, soil-transmitted helminths in Southeast Asia: a systematic review," Parasit Vectors, vol. 9, no. 31, Januari 2016.

[8] M. Werkman, J. E. Wright, J. E. Truscott et all, "Testing for soil-transmitted helminth transmission elimination: Analysing the impact of the sensitivity of different diagnostic tools," Plos Neglected Tropical Diseases, vol. 12, no. 1, Januari 2018.

[9] L. v. Lieshout dan M. Yazdanbakhsh, "Landscape of neglected tropical diseases: getting it right," Lancet Infect Dis, vol. 13, no. 6, 2013.

[10] J. J. Verweij, E. A. T. Brienen, J. Ziem, L. Yelifari, A. M. Polderman dan L. V. Lieshout, "Simultaneous Detection and Quantification of Ancylostoma duodenale, Necator americanus, and Oesophagostomum bifurcum in Fecal Samples Using Multiplex Real-Time PCR," The American Journal of Tropical Medicine and Hygiene, vol. 77, no. 4, pp. 685-690, 2007.

[11] I. Sutanto, I. S. Ismid, P. K. Sjarifuddin dan S. Sungkar, Buku ajar parasitologi kedokteran, Jakarta: Balai Penerbit FKUI, 2008.

[12] R. Subahar, P. Patiah, A. U. widiastuti dan H. Wibowo, "Pravelensi dan Intensitas Infeksi Ascaris Lumbricoides dan Trichuris trichiura pada Anggota Keluarga di Jaarta dan Cipanas, Jawa Barat," Jurnal Profesi Nedika, vol. 11, no. 1, 2017.

[13] Central for Diease Control and Prevention, [Online]. Available: https://www.cdc.gov/parasites/sth/. [Diakses 20 Juni 2020].

[14] World Health Organization, "Soiltransmitteshelminthiases: eliminanting soil transmitted helminthiases as a public helath problem in childern: progress report 20012010 andstrategic plan 2011-2020," WHO, Prancis, 2012.

[15] T. Ni'mah, "Diagnosis STH Menggunakan PCR. Makalah Seminar Umum,” 2-26, 2019. 